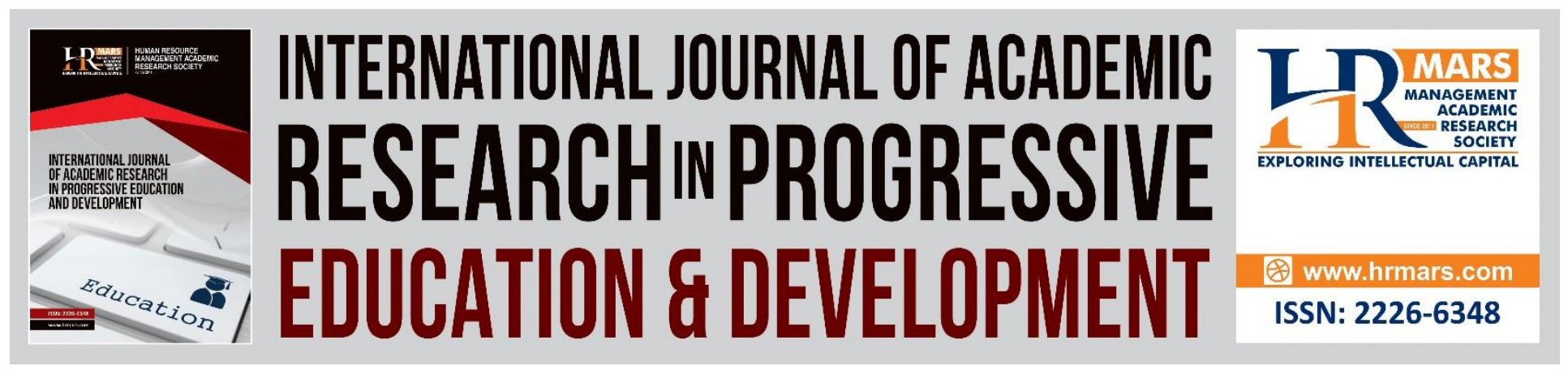

\title{
The Eclectic Approach as a Therapy for Teaching English as a Foreign Language to the Arab Students
}

\author{
Jarrah Mohammad Al-Jarrah, Yahya Zakaria Alkhanous, \\ Rania Hassan Talafhah, Tamer Mohammad Al-Jarrah,
}

To Link this Article: http://dx.doi.org/10.6007/IJARPED/v8-i1/5538

DOI: $10.6007 /$ IJARPED/v8-i1/5538

Received: 18 Jan 2018, Revised: 22 Feb 2019, Accepted: 20 March 2019

Published Online: 22 March 2019

In-Text Citation: (Al-Jarrah et al., 2019)

To Cite this Article: Al-Jarrah, J. M., Alkhanous, Y. Z., Talafhah, R. H., Al-Jarrah, T. M. (2019). The Eclectic Approach as a Therapy for Teaching English as a Foreign Language to the Arab Students. International Journal of Academic Research in Progressive Education and Development, 8(1), 100-113.

\section{Copyright: (C) 2019 The Author(s)}

Published by Human Resource Management Academic Research Society (www.hrmars.com)

This article is published under the Creative Commons Attribution (CC BY 4.0) license. Anyone may reproduce, distribute, translate and create derivative works of this article (for both commercial and non-commercial purposes), subject to full attribution to the original publication and authors. The full terms of this license may be seen at: http://creativecommons.org/licences/by/4.0/legalcode

Vol. 8, No. 1, 2019, Pg. 100 - 113

Full Terms \& Conditions of access and use can be found at http://hrmars.com/index.php/pages/detail/publication-ethics 


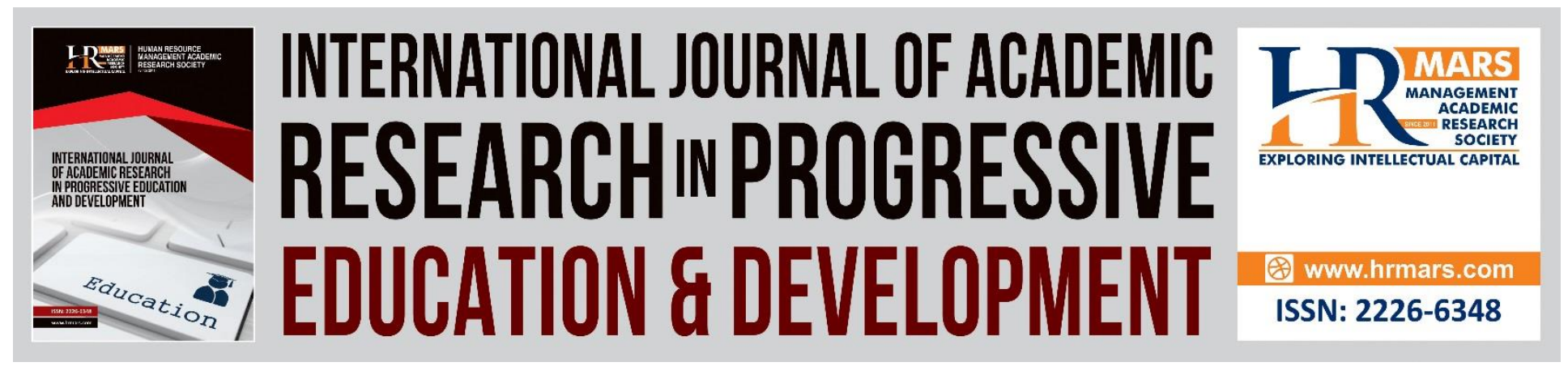

\title{
The Eclectic Approach as a Therapy for Teaching English as a Foreign Language to the Arab Students
}

\author{
Jarrah Mohammad Al-Jarrah ${ }^{1}$, Yahya Zakaria Alkhanous², \\ Rania Hassan Talafhah ${ }^{3}$, Tamer Mohammad Al-Jarrah ${ }^{4}$ \\ ${ }^{1}$ Assistant Professor of TEFL, Department of Educational Studies, Faculty of Islamic Studies, \\ Islamic University of Minnesota, USA \\ ${ }^{2}$ English Teacher, Education International Schools, Kingdom of Saudi Arabia \\ ${ }^{3}$ Assistant Professor of TEFL, Department of Curriculum and Instruction, Faculty of Education, \\ Yarmouk University, Jordan \\ ${ }^{4}$ Department of Language and Communication, Universiti Malaysia Terengganu, 21300 Kuala \\ Nerus, Terengganu, Malaysia
}

Email: almazarmaa@gmail.com,yhyakhnos@gmail.com, rania.talafhah@yu.edu.jo, tameressay@gmail.com, aien@umt.edu.my

\begin{abstract}
The purpose of this study is to examine the Eclectic Approach as a Therapy for Teaching English as a Foreign Language to the Arab Students. The present study is a experimental method which involves both quantitative and qualitative data. The researcher reviews the related literature and his experiment as a teacher at an international school. The participants for this study are two sections of the seventh grade. This sample is consisted of sixty-one male students enrolling for the 2015-2016 academic year. The results of this study show that the eclectic approach gave a chance to students to see different kinds of teaching techniques that break monotony. In addition, the eclectic approach enabled work done with modern teaching aids (e.g. audio-visual aids, computer) to be an extension of the method used in class.
\end{abstract}

Keywords: Eclectic Approach, Therapy, experimental method

\section{Introduction}

Of the living languages, English is by far the most widely used. The status of English intensifies the different varieties of English (Mullany \& Stockwell, 2015, p. 39). It may be argued that several varieties of English exist: British, American, Caribbean, West African, East African, Indian, South-east Asian, and Australasian. Because of these geographically disparate varieties of English there are three presumed kinds of English: those of first language where English is the 
DEVELOPMENT

Vol. 8, No. 1, 2019, E-ISSN: 2226-6348 ๑ 2019 HRMARS

mother tongue (MT), as in the USA or Australasia, and second language (SL) situations, where English is the language of commercial, administrative and educational institutions, as Ghana or Singapore.

In the Arab countries, or in foreign situations of this kind, the learners of English tend to have an instrumental motivation for English. Likewise, dramatic changes take place in foreign language teaching methodology, but it is noticed that some of the teachers have no interest of these recent changes. Those teachers are still following traditional approaches and methods (chalk and talk) in which the teacher is the only speaker and the students have practically got nothing to do other than listening to what the teacher says, no matter whether they enjoy it or not. Also, some teachers still focus too much on lexical and grammatical points and pay less attention to practice in various skills and strategies to develop the learners' creativity of skills like reading or writing (Ubeid, 2013, p. 3).

Statement of The Problem

This study presumes that the eclectic approach is the label given to a teacher's use of techniques and activities from a range of language teaching approaches and methodologies. The teacher decides what method or approach to use depending on the aims of the lesson and the learners in the group. Any typical lesson might combine elements from various sources, accordingly an ESL teacher uses a variety of approaches to teach adult learners to speak, read, and write English (Harris and Turkington, 2006, p.105). So far from teachers following one specific methodology, I am to apply, in my experiment, a bunch of methods to illustrate the advantages of the eclectic approach to the students' achievement.

Eclectic Approach can be described as a desirable, coherent, pluralistic approach to language teaching. The Eclectic Approach involves the use of a variety of language learning activities and strategies, each of which may have very distinctive characteristics and may be motivated by different underlying assumptions. The Eclectic Approach is a necessity since there are strengths as well as weaknesses of methods based on a single theory. Dependence upon a sole hypothesis of teaching is criticized because the use of a limited number of techniques can become mechanic. The students, thus, cannot get benefits of learning (Mellow, 2002, p.1).

English language in Saudi Arabia, my case study, has been taught for a long time. English has been taught with lesser expertise and it has also been suffering due to lack of strong pedagogical traditions. To improve this situation, it is important to encourage a move towards an eclectic method of teaching. This introduces a new and innovative paradigm of the teacher's role as an informed decision-maker in the classroom and specifies new directions for classroom pedagogies. Therefore, there is currently a search for broader guiding principles to the complex choices teachers make in their classroom interaction (Gulzar et al., 2014, p.4).

Objective of and Question of The Study

The objective of the current study can be summed up in three points: first, the study revisits the applications of the eclectic method in English learning and teaching. Second, the study discusses the Eclectic approach as a therapy for teaching English as a foreign language. Based on these objectives, research question can be formulated to prove by the end of the research, Can the eclectic approach be considered as a therapy for teaching English as a foreign language to the Arab students? 


\section{Significance of The Study}

The value of this study can be explained in three points. Firstly, the theoretical value is hoped to be existed by providing knowledge concerning new and fruitful techniques and methods in language learning and teaching. Secondly, the findings would inform those who work in the field of foreign language teaching like trainees, teachers, supervisors and curriculum designers on the merits of the eclectic method. Thirdly, the study evaluated the eclectic method. This may open the door to discuss the role of the methods of teaching at various levels of language learning: primary, secondary and college levels.

\section{Literature Review}

\section{The Eclectic Approach in Teaching English}

Through looking on the educational field from the perspective of knowledge management, English teachers learn about efficient knowledge and from this viewpoint; they adjust their teaching methods and make ongoing learning an integral part of their teaching strategies (Han-Kwang, 2012, pp. 64-65). Under the principles of cognitive theory, knowledge that makes sense and has significance to children is more meaningful than inert knowledge and knowledge learned by rote. To support students' innovation and discovery, inspiring education calls for educators to integrate the powerful technology seamlessly into the learning process (Friesen, 2013, p.4).

Language learning can be seen as a combined process of structural and communicative activities towards a communicative approach (Beltran and Others, 2013, p.1998). They must have some philosophical backgrounds and some systematic relation among different activities. Usually, it is recommended to mix structural approaches with communicative use of language. This does not mean to mix up different approaches randomly. The kind of combination to be implemented is a mixture of traditional reading based approach and some conversational practice for students. Indeed, if there are conflicting approaches in one's instructional techniques, one may have contrary results to those one he is striving for (Weideman, 2007, p.7).

Here, the eclectic approach reveals such an attempt by the teachers to deal with complex teaching situations. However, more attention should be centered on the cognitive, affective, contextual and experiential factors related to language teaching and learning when making decisions in classrooms. Methods, post-methods, macro-strategies and approaches are heuristic in providing coherent principles, which we, as teachers, can use to challenge and clarify our own beliefs in order to come up with rational decisions. Accordingly, any teacher training program should not be limited to specific methods and approaches (Zheng; 2015, p.166).

In line with the policy of training programs, Lin and Man $(2009$, p.52) emphasize that learner-centered approach to language teaching and learning incorporates structured teacherinput and whole-class group activities. The focus is therefore to be placed on how the teacher can address the needs of almost each individual learner. Practically, to ensure that the particular needs of teachers and learners in the context should be met, basic interactive communication skills and cognitive academic language proficiency are emphasized and achieved by means of both cooperative and individualized learning through a variety of activities. Simply put, the inclass activities for example should be well tailored according to the different learning style learners may require, and collective activities are much less encouraged. 
DEVELOPMENT

Vol. 8, No. 1, 2019, E-ISSN: $2226-6348 @ 2019$ HRMARS

\section{Is eclecticism a therapy?}

Students nowadays always want something new and exciting, so learning should not be boring and stressful. Based on the teacher's teaching experience, students enjoy going to school. They love the environment and they are excited about what they are going to learn for the day. They have a positive concept of what a school is and learning becomes easier for them. The eclectic approach is very appropriate for the students as it represents a chance for the children to develop all the essential life skills by learning in a creative and stimulating environment and gaining the confidence to fulfill their potentials as learners. Children are more likely to use prosocial behaviors when their teachers use positive guidance strategies and a curriculum that emphasizes the value of community (Schmidt \& Others, 2007, 290-301).

Much of psychotherapists and counselors today identify themselves with some form of "eclectic therapy." Basically, a therapist borrows techniques from a variety of schools and points of view, and tailors the treatment to the specific needs of each client. In such a manner, theoretical techniques from the various schools of psychology-psychoanalytical, dispositional, phenomenological, and behavioral / cognitive - may be used in accordance with the needs of the patient. Therapeutic techniques may be as varied as the individual's personality dictates. The more thoroughly instructors understand the differences, the better chance they have of meeting the diverse learning needs of all their students (Felder and Brent, 2005, p.1). English teachers should use a collection of all the good points of different methods. Naturally any one method does not serve the purpose of teaching languages well for all times and in all types of teaching situations. Teachers should, first of all, analyze their pupils and according to them and to the situation in which they are going to teach, one or a mixture of several of the methods displayed above would surely fit best their learners' and their own needs (Elizabeth, 2010, p.211).

An eclectic approach, to Davis and Lani (2004, p.14), that is usually adopted and practiced, is influenced by the experience and expertise of staff and of visiting professionals (i.e. speech and language therapists and educational psychologists). This is not to suggest an approach to teaching and learning in which 'anything goes'. Rather we agree with those commentators who suggest that the theoretical models which give rise to different teaching approaches and strategies may not be as disparate as initially thought. Behavioral, social constructivist and ecosystemic approaches to teaching and learning all contribute to pedagogy. The question is no longer which approach is best, but how we apply what has been learned from each of these models in ways that produce positive outcomes such as increased attainment and achievement.

Therapists argue that they are in the best possible position to help clients, because they have every treatment method at their disposal. Critics counter that it is impossible to know any single method well, because there are just too many methods. This acknowledges the need for credibility among therapists, while at the same time offering several systematic models which help to bolster claims, which they offer what patients need. The eclectic therapy is considered to be one of the most important trends in contemporary psychology. This movement owes its rise to the belief that no single system or theory can lay claim to the possession of psychotherapeutic 'truth,' or to a clear-cut superiority in therapeutic. The eclectic approach seems to be the most practical one because most learners are studying English in order to use it in real life situations (Christison and Murray, 2014, p.74).

We, as teachers, use each and every method, process, exercise, drill, or device which may further help us in our immediate purpose and bring us nearer to our ultimate goal; we adopt 
DEVELOPMENT

Vol. 8, No. 1, 2019, E-ISSN: 2226-6348 ๑ 2019 HRMARS

every good idea and leave the door open for all future development; we reject nothing except useless and harmful forms of work. The multiple line of approach embodies the eclectic principle. This approach enjoins us to select, judiciously and without prejudice, all that is likely to help us in our work. To Piller and Skillings $(2005$, p.11) this approach, while not ignoring formal instruction in grammar and language structure, it provides immersion in oral language, it is contextualized in true to life situations, and it attends to appropriate interactions in social context.

A teacher working on an eclectic approach, therefore, tries to use all the best techniques of the entire well - known methods in his classroom procedures. He should, however, be in a balanced development of all four skills at all stages, with an emphasis being placed on the early development of oral skills. Teachers change their methods to suit particular types of learners and to meet the objectives of the course. They are expected to be imaginative, energetic, willing to experiment in order to make their lessons interesting and to use a variety of techniques. It is suggested that no single teaching methodology can be sufficient to address diverse and peculiar needs of English learners, and practitioners have to pick and choose from a host of teaching methodologies to run an effective course. The needs of learners are specific and ready-made teaching materials do not suit their learning objectives (Javid, 2015, p.24).

To add on, differentiated instruction can become best productive by the use of "a mix of methods combined with wisdom, logic, a sound knowledge of educational psychology and seasoned artistry" as (Pham, 2012, p.13). Today many people use a mixing method of teaching to adjust to the requirements for achieving the purpose of teaching without the need to face many difficulties as the use of one particular method. Therefore, an eclectic use of methods based only on the best parts or parts that are beneficial from a variety of teaching methods, then the weaknesses of a particular teaching method can be avoided. In other words, when teachers use this method, teachers can avoid the problems that occur when delivering the teaching material. In addition to the method of teaching and learning in an activity, teachers can easily adapt to the needs of teaching so that teaching objectives or goals can be achieved.

Al-Obaidli (2009) and Al-Jarrah et al. (2019) investigated the perceptions of women ESL teachers regarding Qatar's reforms and their experiences using new approaches to teaching ESL. Professional development needs were also identified. After analysis and presentation of the findings, it is concluded that while educational reform in Qatar had been largely conceptualized from the top down, close attention is still needed regarding the role of women ESL teachers in the process of implementation, in particular, since reform is dependent upon sustained professional development for ESL teachers. The Supreme Education Council should explicitly document the strategic objectives for education for a new era, based on a clear analysis and definition of the underlying philosophy and vision for reform and transformation of Qatar's public education. The Supreme Education Council should provide more overt guidance and direction to schools and other stakeholders, which goes well beyond the 'technical' nature of fiscal contracts between schools and the Supreme Education Council. It should also be instrumental in helping to build networks of schools and teachers so that 'independence' does not come to mean professional isolation and remoteness, and it should become more aware of the challenges facing the reform process in schools and classrooms.

Al-Rubaie (2010) was concerned with the educational aspects of such influences where it explored trainee teachers' conceptualizations of English as an international / global language, 
DEVELOPMENT

Vol. 8, No. 1, 2019, E-ISSN: 2226-6348 ๑ 2019 HRMARS

and examined the implications of current views of English for teacher preparation in light of the most recent methodological trends such as global English delivery, expansion of teacher knowledge base, the introduction of linguistic rights and instructional policies to educational stakeholders, and the merging of language and culture in English language teaching. Therefore, the researcher recommended bringing to the forefront the opinions of practitioners, which may illuminate and inform theoretical perspectives on ELT outside the inner circle as well as teachers' preparation curricula. The experiences of those who teach may reveal important and efficient methods of English language delivery which may hold relevance for the global English trend.

The researcher suggested contacting these same novice instructors again during their first few years of school placement to reveal further factors that would affect their motivation and competencies. It would also be useful to contact school administrators to discuss possible remediation strategies that would retain new teachers in the profession. The involvement of trainee teachers could enrich the existing body of literature, which lacked studies about English language teaching in Kuwait paired with the issues of globalization, international English, the future of English in the Kuwaiti sociolinguistic context, and the dialogue between source (Arabic) and target (English) cultures. It became evident that Kuwait's ELT educational authorities relied heavily on guidelines and recommendations provided by experts from Great Britain and the USA, as well as various international organizations and committees. Kuwait's educational authorities should trust local experts, rather than non-judgmentally following imported teaching / learning models, which can work within the main principles of cultural imperialism and could be too impactful on Kuwaiti local culture. Al-Rubaie proposed that Kuwait's authorities enroll local theorists and practitioners to modify those external guidelines according to the specifics of the country and its educational stakeholders.

Al Mawoda (2011) and Al-Jarrah, Talafhah, and Al-Jarrah, (2019) saw that teacher education requires providing learning opportunities which are both cognitive and experiential, and accepting that language teachers are the most important mediators where they need to reflect on their experience as well as implement comparative analysis of their own culture and target culture. Also, teachers need to appreciate the implications of cultural learning, both knowledge and skills, for their practices in the classroom in addition to their teaching in the field. The responsibilities of language teachers are enormous for introducing learners, at any age to learning. The teachers provide challenging and thought provoking, and they modify their awareness of the world and their cultural identity, as members of a given social and national group. The researcher presented the following recommendations as to how ELT could be developed in a more intercultural direction:

1. The role of English as an international language must be stressed and ELT must aim at turning students into cultural mediators and competent intercultural language users, rather than unsuccessful deficient native speakers.

2. Culture must not be considered as a fifth skill, introduced only if there is time. Rather it should permeate everything that is done in the English language classroom, and be thought about from a process perspective, rather than the traditional product perspective.

3. Values and ways of thinking should be discussed rather than pure information of facts, which language education has traditionally encouraged.

4. Classroom activities should be encouraged, which include intercultural encounters, as a method for awakening the students' empathy and respect for otherness. 
Vol. 8, No. 1, 2019, E-ISSN: 2226-6348 @ 2019 HRMARS

\section{Research Methodology \\ Research Design}

The present study was conducted in an experimental method. The research setting snuggly provided pre-test, post-test and an achievement test which were administered by the researcher himself to the experimental group and the control group selected and designed for current study.

Population and Sample

The selected sample of the participants was two sections of the seventh grade 2015 2016 at the intermediate stage of International Schools, Riyadh, Saudi Arabia. They were chosen within the same range of abilities and achievement.

The research sample consists of (61) male students officially enrolled for the Academic year 2015 - 2016 at an International Schools in Riyadh, KSA. Interestingly, the participants come from different sociocultural and socioeconomic backgrounds, including multinational Arab students (Saudi, Egyptian, Syrian, Sudanese, Lebanese, Palestinian, Jordanian and Yemeni) and mixed academic abilities.

Experimental Procedure

In the first week, a pretest was administered to both groups to check initial group achievements and to help control the non-randomization effect, which is a potential threat to internal validity with the design. Then, the taught lessons lasted roughly for (50) minutes in each group. While the two groups were taught through the aid of a smart board and an overhead projector, the control group was taught using the conventional method of lecturing and open class discussion, and the experimental group was taught through the Principled Eclecticism which is a fitting method for the learner, not the learner to the method.

At the end of the treatment, in the seventh week, both groups were given a posttest. The pretest is in appendix (2) and the post-test is in appendix (3). The results of the pretest and posttest revealed by the research study are displayed in the table (5):

\begin{tabular}{|c|c|c|c|c|c|}
\hline \multicolumn{6}{|c|}{ Table 5: Results of Pretest and Posttest for the Experimental and Control Groups } \\
\hline \multicolumn{3}{|c|}{ Experimental Group } & \multicolumn{4}{c|}{ Control Group } \\
\hline Student Number & Pretest & Posttest & Student Number & Pretest & Posttest \\
\hline 1. & 6 & 16 & 1. & 10 & 12 \\
\hline 2. & 6 & 16 & 2. & 7 & 15 \\
\hline 3. & 9 & 18 & 3. & 11 & 15 \\
\hline 4. & 5 & 18 & 4. & 13 & 13 \\
\hline 5. & 11 & 18 & 5. & 7 & 12 \\
\hline 6. & 1 & 17 & 6. & 13 & 19 \\
\hline 7. & 20 & 20 & 7. & 1 & 9 \\
\hline 8. & 17 & 18 & 8. & 16 & 12 \\
\hline 9. & 10 & 14 & 9. & 1 & 19 \\
\hline 10. & 20 & 20 & 10. & 3 & 7 \\
\hline 11. & 2 & 20 & 11. & 11 & 17 \\
\hline 12. & 13 & 16 & 12. & 16 & 20 \\
\hline 13. & 17 & 20 & 13. & & \\
\hline
\end{tabular}




\section{INTERNATIONAL JOURNAL OF ACADEMIC RESEARCH IN PROGRESSIVE EDUCATION AND}

DEVELOPMENT

Vol. 8, No. 1, 2019, E-ISSN: $2226-6348$ @ 2019 HRMARS

\begin{tabular}{|c|c|c|c|c|c|}
\hline \multicolumn{6}{|c|}{ Table 5: Results of Pretest and Posttest for the Experimental and Control Groups } \\
\hline \multicolumn{3}{|c|}{ Experimental Group } & \multicolumn{3}{c|}{ Control Group } \\
\hline Student Number & Pretest & Posttest & Student Number & Pretest & Posttest \\
\hline 14. & 20 & 20 & 14. & 1 & 9 \\
\hline 15. & 13 & 18 & 15. & 11 & 20 \\
\hline 16. & 16 & 18 & 16. & 14 & 19 \\
\hline 17. & 16 & 19 & 17. & 17 & 19 \\
\hline 18. & 7 & 14 & 18. & 10 & 15 \\
\hline 19. & 16 & 18 & 19. & 8 & 19 \\
\hline 20. & 13 & 19 & 20. & 20 & 20 \\
\hline 21. & 12 & 15 & 21. & 10 & 19 \\
\hline 22. & 1 & 18 & 22. & 18 & 20 \\
\hline 23. & 6 & 15 & 23. & 16 & 19 \\
\hline 24. & 15 & 18 & 24. & 15 & 17 \\
\hline 25. & 9 & 17 & 25. & 1 & 9 \\
\hline 26. & 20 & 20 & 26. & 13 & 20 \\
\hline 27. & 20 & 20 & 27. & 12 & 19 \\
\hline 28. & 20 & 20 & 28. & 13 & 19 \\
\hline 29. & 8 & 18 & 29. & 19 & 19 \\
\hline
\end{tabular}

In the last week, the eighth week of the study, an achievement test was handed to the two groups of students. The achievement test is in appendix (5). Table (6) shows the achievement test results of the both groups.

\begin{tabular}{|c|c|c|c|}
\hline \multicolumn{3}{|c|}{ Table 6: Results of Achievement Test of Experimental and Control Group. } \\
\hline \multicolumn{3}{|c|}{ Experimental Group } & \multicolumn{2}{c|}{ Control Group } \\
\hline 30 & 28 & 30 & 21 \\
\hline 30 & 28 & 30 & 20 \\
\hline 30 & 27 & 29 & 19 \\
\hline 30 & 27 & 29 & 19 \\
\hline 30 & 26 & 29 & 17 \\
\hline 29 & 25 & 28 & 16 \\
\hline 29 & 25 & 28 & 15 \\
\hline 29 & 24 & 28 & 15 \\
\hline 29 & 23 & 27 & 14 \\
\hline 29 & 21 & 26 & 11 \\
\hline 29 & 21 & 26 & 11 \\
\hline 29 & 19 & 26 & 9 \\
\hline 29 & 18 & 24 & 4 \\
\hline 28 & 14 & 23 & 4 \\
\hline 28 & & 22 & 3 \\
\hline
\end{tabular}




\section{Methods of Data Analysis}

More importantly, qualitative analysis attempts to increase the general understanding of the characteristics, quality and purpose of the topic under research. In addition, the researcher conducts data analysis within the larger context of his or her research design set within a theoretical framework. Taking the whole research all the way long to the final stage is to be sorted out by the painstaking and meticulous process of data analysis: data analysis is sifting and sorting the body of information culled from the set sources about the concept hypothesized by the research to determine its meaning and uncover its function and how it operates, as well.

Mean and standard deviation scores were used to analyze the data collected through the pretest and posttest. Using the SPSS Statistics program, the researcher analyzed the results of the pretest and the posttest of the experimental group and control group. And table (7) shows the means of the two groups. The dependent variable was the posttest.

\begin{tabular}{|c|c|c|c|}
\hline \multicolumn{3}{|c|}{ Descriptive Statistics } \\
\hline \multicolumn{3}{|c|}{ Dependent Variable: Posttest } \\
\hline Group & Mean & Std. Deviation & $\mathrm{N}$ \\
\hline 1.00 & 17.8621 & 1.86556 & 29 \\
\hline 2.00 & 15.8276 & 4.12370 & 29 \\
\hline Total & 16.8448 & 3.33404 & 58 \\
\hline
\end{tabular}

Table 7: Mean and Standard Deviation of Pretest and Posttest of the Experimental and Control Groups

Achievement tests are often used in educational settings. An achievement test in respect of consisting of 30 close-ended questions has been prepared in order to realize the general purpose of the research. Some experts' opinions have been sought for test validity and in accordance with these opinions the pilot scheme has been applied to the students. Table (8) shows the mean and standard deviation of achievement test of the experimental and control groups.

\begin{tabular}{|c|c|c|c|c|c|}
\hline \multicolumn{6}{|c|}{$\begin{array}{c}\text { Table 8: Mean and Standard Deviation of Achievement Test of the Experimental and Control } \\
\text { Groups }\end{array}$} \\
\hline \multicolumn{6}{|c|}{ Group Statistics } \\
\hline & Method & $\mathrm{N}$ & Mean & Std. Deviation & Std. Error Mean \\
\hline \multirow{2}{*}{ Mark } & 1.00 & 29 & 26.3448 & 4.17711 & .77567 \\
\hline & 2.00 & 30 & 20.1000 & 8.34328 & 1.52327 \\
\hline
\end{tabular}

Results Analysis

Results Analysis and Discussion

Analysis in tables (5-7-9) - results analysis of the pretest and post-test, and in tables (6-810) - results analysis of the achievement test revealed that the experimental group obtained higher mean scores than the control group. This indicates that the eclectic approach enhanced the experimental students' ability to produce more syntactically correct utterances (Understanding Conjunctions) within the available time more than the control group students. 
INTERNATIONAL JOURNAL OF ACADEMIC RESEARCH IN PROGRESSIVE EDUCATION AND DEVELOPMENT

Vol. 8, No. 1, 2019, E-ISSN: $2226-6348$ @ 2019 HRMARS

\begin{tabular}{|c|c|c|c|c|c|}
\hline \multicolumn{7}{|c|}{ Tests of Between-Subjects Effects } \\
\hline \multicolumn{7}{|c|}{ Dependent Variable: Posttest } \\
\hline Source & $\begin{array}{c}\text { Type III Sum of } \\
\text { Squares }\end{array}$ & Df & Mean Square & $\mathrm{F}$ & Sig. \\
\hline Corrected Model & $325.984^{\text {a }}$ & 2 & 162.992 & 29.142 & .000 \\
\hline Intercept & 1887.845 & 1 & 1887.845 & 337.532 & .000 \\
\hline Pretest & 265.967 & 1 & 265.967 & 47.553 & .000 \\
\hline Group & 31.226 & 1 & 31.226 & 5.583 & .022 \\
\hline Error & 307.619 & 55 & 5.593 & & \\
\hline Total & 17091.000 & 58 & & & \\
\hline Corrected Total & 633.603 & 57 & & & \\
\hline Table 9: Results Analysis of Pretest and Posttest of the Experimental and Control Groups \\
\hline
\end{tabular}

\begin{tabular}{|c|c|c|c|c|c|c|c|c|c|c|}
\hline \multicolumn{11}{|c|}{ Table 10: T-Test Of The Achievement Test } \\
\hline \multicolumn{11}{|c|}{ Independent Samples Test } \\
\hline & & \multicolumn{2}{|c|}{$\begin{array}{l}\text { Levene's Test } \\
\text { for Equality } \\
\text { of Variances }\end{array}$} & \multicolumn{7}{|c|}{ t-test for Equality of Means } \\
\hline & & \multirow[t]{2}{*}{ f } & \multirow[t]{2}{*}{ Sig } & \multirow[t]{2}{*}{$\mathrm{t}$} & \multirow[t]{2}{*}{ Df } & \multirow{2}{*}{$\begin{array}{l}\text { Sig } \\
(2- \\
\text { tailed } \\
\quad)\end{array}$} & \multirow[t]{2}{*}{$\begin{array}{l}\text { Mean } \\
\text { Differen } \\
\text { ce }\end{array}$} & \multirow{2}{*}{$\begin{array}{c}\text { Std. } \\
\text { Error } \\
\text { Differe } \\
\text { nce }\end{array}$} & \multicolumn{2}{|c|}{$\begin{array}{l}95 \% \text { Confidence } \\
\text { Interval of the } \\
\text { Difference }\end{array}$} \\
\hline & & & & & & & & & $\begin{array}{c}\text { Lowe } \\
r\end{array}$ & Upper \\
\hline \multirow[t]{2}{*}{$\begin{array}{l}\text { Ma } \\
\text { rk }\end{array}$} & $\begin{array}{l}\text { Equal } \\
\text { varianc } \\
\text { es } \\
\text { assume } \\
\text { d }\end{array}$ & $\begin{array}{r}15.3 \\
74\end{array}$ & $\begin{array}{r}.00 \\
0\end{array}$ & $\begin{array}{r}3.6 \\
16\end{array}$ & 57 & .001 & 6.24483 & $\begin{array}{r}1.7271 \\
4\end{array}$ & $\begin{array}{r}2.786 \\
29\end{array}$ & $\begin{array}{c}9.7033 \\
7\end{array}$ \\
\hline & $\begin{array}{l}\text { Equal } \\
\text { varianc } \\
\text { es not } \\
\text { assume } \\
d\end{array}$ & & & $\begin{array}{r}3.6 \\
53\end{array}$ & $\begin{array}{r}42.9 \\
95\end{array}$ & .001 & 6.24483 & $\begin{array}{r}1.7093 \\
9\end{array}$ & $\begin{array}{r}2.797 \\
51\end{array}$ & $\begin{array}{c}9.6921 \\
5\end{array}$ \\
\hline
\end{tabular}

\section{Discussion}

Analysis of responses to the posttest and achievement questions reveals that the significance level is ( $\alpha=0.022$ and $\alpha=001)$, and this significance level is smaller than $(\alpha=0.05)$. This reveals that the eclectic approach enhanced students' ability to produce grammatical sentences, to accurately place the correct conjunction and then identify the type of this 
INTERNATIONAL JOURNAL OF ACADEMIC RESEARCH IN PROGRESSIVE EDUCATION AND

DEVELOPMENT

Vol. 8, No. 1, 2019, E-ISSN: 2226-6348 @ 2019 HRMARS

conjunction either subordinating, correlative or coordinating conjunction more than conventional English language instruction used when teaching the control group. This manifests that one of the major premises of eclecticism is that teaching should serve pupils not methods. Thus, the researcher felt free in choosing techniques and procedures inside the classroom, because there is no ideal approach in language learning. Each one has its merits and demerits. There is no loyalty to certain methods. The researcher had the right to choose the best methods and techniques according to the pupils' needs and the learning situation. The researcher adopted a flexible method and technique so as to achieve his goals. He chose whatever works best at a particular time in a particular situation.

The researcher explains these significant results ( $\alpha=0.022$ for the pretest and posttest; and $\alpha=001$ for the achievement test) after analyzing the results of pretest, post-test and achievement test. The research sees the following reasons that stand behind these excellent results:

1. The eclectic approach gave a chance to students to see different kinds of teaching techniques that break monotony.

2. The eclectic approach was simple for both teacher and learner, and within the capabilities of all teachers. Also, the eclectic approach let the teacher feel that pupils are progressing satisfactorily.

3. The eclectic approach brought about a balance between the spoken and written or printed word.

4. The eclectic approach overcame the conflict between fluency and accuracy.

5. The eclectic approach reflected the linguistic habits the child has already acquired by learning his/her mother tongue and their ability to assimilate a new language.

6. The eclectic approach enabled work done with modern teaching aids (e.g. audio-visual aids, computer) to be an extension of the method used in class.

7. The eclectic approach was sufficiently flexible to cope with various class conditions as far as pupils' specific / general interests are concerned.

8. The eclectic approach ensured that pupils were given the opportunity of having the greatest number of meaningful contacts possible both with and in the foreign language.

The results of this study support the assumption that the eclectic approach is a useful approach for ESL learners. The eclectic approach is the most effective language learning approach proposing that an effort should be made to use more than one learning mode in the learning process. Hence, the learning effect is maximized. This is because learning tasks and components of different nature benefit the students from particular types of learning mode. Also, the eclectic approach is desirable for the curriculum designers as Qian and Li (2014, p. 184)

\section{References}

Alamri, A. A. M. (2008). An evaluation of the sixth grade English language textbook for Saudi boys' schools. King Saud University, 6(3), 160-165.

Al-Asmari, A. M. and Khan, S. R. (2014). World Englishes in the efl teaching in Saudi Arabia. Arab World English Journal, 5(1), 20-25.

Al-Jarrah, J. M., Talafhah, R. H., \& Al-Jarrah, T. M. (2019). Social networking sites and English language learning: Jordanian EFL learners 'practices and experiences. European Journal of English Language Teaching. 6(2), 70-75. 
Al-Jarrah, T. M., Mansor, N., Talafhah, R. H., \& Al-Jarrah, J. M. (2019). The application of metacognition, cognitivism, and constructivism in teaching writing skills. European Journal of Foreign Language Teaching, 5(3), 177-180.

Al-Musallam, E. I. (2009). College instructors' and learners' attitudes to authentic EFL reading materials In Saudi Arabia . King Saud University. 4(1), 180-190.

AL-SHEHRI, K. D. (2008). Teachers' and students' attitudes toward formative assessment and feedback in teaching English for specific purposes ESP. Asian-EFL journal. com>downloads. 6(1), 155-163.

Babbie, Earl R. (2007). The Practice of Social Research. Wadsworth Publishing Compan. 6(3), 7077.

Bayyurt, Y., \& Akcan, S. (Eds.). (2015). Current perspectives on pedagogy for English as a lingua franca (Vol. 6). Walter de Gruyter GmbH \& Co KG. 6(4), 60-65

Brooks, K. W. (2015). Introduction to TESOL: A beginners approach to teaching speakers of other languages. Lulu. com. 5(4), 110-115.

Chen, H. K. (2012). Efficient analysis of cognitive and eclectics English learning approaches from the perspective of era of knowledge economy-an experimental study of preschool education. The Journal of Human Resource and Adult Learning, 8(1), 63.

Connaway, L. S., \& Radford, M. L. (2016). Research methods in library and information science. ABC-CLIO. 4(5), 150-155.

Crystal, D. (2012). English as a global language. Cambridge university press.

Dash, Neena \& Dash, M. (2007). Teaching English as an additional language. Atlantic Publishers \& Dist, 6(3), 120-127.

DePoy, Elizabeth and Gitlin, Laura N. (2013). Introduction to research: understanding and applying multiple strategies. Elsevier Health Sciences, 4(3) 134-138.

Dziewulska, A. (Ed.). (2012). Practitioners' Advice on EU project management. Agata Dziewulska. 3(3), 120-125.

Frede, E., \& Ackerman, D. J. (2006). Curriculum decision-making: Dimensions to consider. Document retrieved February, 15, 2007.

Friesen, S., \& Scott, D. (2013). Inquiry-based learning: A review of the research literature. Alberta Ministry of Education. 3(3), 119-127

Genç, B., \& Bada, E. (2010). English as a world language in academic writing. The Reading Matrix, 10(2).

Herrera, S. G., Perez, D. R., Kavimandan, S. K., \& Wessels, S. (2013). Accelerating Literacy for Diverse Learners: Strategies for the Common Core Classroom, K 8. Teachers College Press. 2(3), 11-14.

Kumar, C. P. (2013). The eclectic method theory and its application to the learning of English . International Journal of Scientific and Research Publications, 3(6), 118-129.

Li, J. (2012). Principles of effective English language learner pedagogy. Research in Review 20123. College Board. 6(3), 113-120

$\mathrm{Li}, \mathrm{W}$. (2012). An eclectic method of college English teaching. Journal of language teaching and research: Academy Publisher Manufactured in Finland. 5(4), 13-20

Lin, A. and Man, E. Y. F. (2009). Bilingual education: Southeast Asian perspectives. Hong Kong University Press. 7(2), 45-51 


\section{INTERNATIONAL JOURNAL OF ACADEMIC RESEARCH IN PROGRESSIVE EDUCATION AND}

\section{DEVELOPMENT}

Vol. 8, No. 1, 2019, E-ISSN: 2226-6348 @ 2019 HRMARS

Łyda, A., Szcześniak, K. (2013). Awareness in action: The role of consciousness in language acquisition. Springer Science \& Business Media. 4(2), 19-27

Mansbach, R. W., \& Ferguson, Y. H. (2012). Globalization: the return of borders to a borderless world?. Routledge. 6(3), 113-120.

McBurney, D. H., White, T. L. (2013). Research methods. Eights Edition. Wadsworht, Cengage learning. 6(4), 13-20

Mitchell, M. L. \& Jolley, J. M. (2017). Research design explained. 8th Edition. Wadsworth Cengage Leraning. 5(1), 66-72

Namdal, A. (2005). Teaching English to young learners in Norwegian compulsory education . Bergen University College.

Oura, G. K. (2001). Authentic task-based materials: Bringing the real world into the classroom. Sophia Junior College Faculty Bulletin, 21, 65-84.

Patton, M. Q. (2002). Two decades of developments in qualitative inquiry: A personal, experiential perspective. Qualitative social work, 1(3), 261-283.

Pradhan, M., Joshi, U., Aryal, U. R., Upadhyay, S., \& Shrestha, A. (2015). Knowledge about emergency management of dental trauma among school teachers of Bhaktapur Nepal. Journal of Kathmandu Medical College, 4(3), 77-82.

Qian, D. D., \& Li, L. (Eds.). (2014). Teaching and learning English in East Asian universities: Global visions and local practices. Cambridge Scholars Publishing. 11, 75-84.

Richards, J. C., Rodgers, T. S. (2014). Approaches and methods in language teaching. Cambridge University Press. 4(3), 65-77.

Richards, J. C. (2013). Curriculum approaches in language teaching: forward, central, and backward design. RELC Journal. 44(1), 23-44.

Riddell, D. (2014). Teach English as a Foreign Language: Teach Yourself (New Edition): eBook. Hachette UK. 4(1), 35-45.

Somatkar, B.W. (2012). Aims and objectives of teaching English in India. Indian Streams Research Journal. 1(5), 1-4.

Takezawa, K. (2014). Learning regression analysis by simulation. Springer. 3(5), 12-24.

Tulkki, H. (2013). Needs analysis for language course design: a holistic approach to esp . Cambridge University Press. 3(5), 22-45.

Turkington, C., \& Harris, J. (2006). The encyclopedia of learning disabilities. Infobase Publishing. $6(2), 11-12$

Wali, N. H. (2009). Eclecticism and language learning. Al-Fatih Journal, 39, 34-41.

Wallen, N. E., \& Fraenkel, J. R. (2013). Educational research: A guide to the process. Routledge.

Wright, W. E. (2010). Foundations for teaching English language learners: Research, theory, policy, and practice. Caslon Pub. 1(5), 11-24.

Zegeye, A., \& Harris, R. L. (Eds.). (2003). Media, identity and the public sphere in post-apartheid South Africa (Vol. 88, 45-65). Brill. 